\title{
Determination of Feed Values of Different Physical Processed Common Vetch Seed (Vicia Sativa) by in Vitro Gas Production Technique
}

\author{
Yasemin Işık ${ }^{1, a}$, Adem Kaya ${ }^{2, b, *}$ \\ ${ }^{l}$ Almus District Directorate of Food Agriculture and Livestock, 60900 Tokat, Turkey \\ ${ }^{2}$ Department of Animal Science, Agricultural Faculty, Atatürk University, 25240 Erzurum, Turkey
}

*Corresponding author

A R T I C L E IN F O A B S T R A C T

Research Article

In this study, in vitro gas production values, gas production parameters $(\mathrm{a}, \mathrm{b}, \mathrm{a}+\mathrm{b}$ and $\mathrm{c})$ and organic matter digestibilities (OMD), metabolizable energy $(\mathrm{ME})$, net energy lactation $\left(\mathrm{NE}_{\mathrm{L}}\right)$ contents, chemical compositions and feed values of different physical processed (raw, soaked, boiled and roasted) common vetch seeds (Vicia sativa) were determined by in vitro gas production technique. Rumen fluid, used in this study, was obtained by probe from one Holstein bull (seven years old, average live weight $=650 \mathrm{~kg}$ ) raised at Research and Application Farm of Agricultural Faculty Atatürk University. Raw and treated common vetch seeds were incubated for 2, 4, 6, 8, 12, 24, 48, 72 ve 96 hours for the determination of in vitro gas production values and gas production parameters in rumen fluid. It was observed significant differences among all of the common vetch seeds in terms of chemical composition (DM, CA, OM, CP, EE, NDF, ADF, ADL) values $(\mathrm{P}<0.05)$. The differences in the chemical composition values affected in vitro gas production values and gas production parameters of raw and treated common vetch seeds. OMD, ME and $\mathrm{NE}_{\mathrm{L}}$ values of common vetch seeds were determined as 63.50-83.10\%, 11.23-14.55 MJ/ kg DM and 5.81-7.99 $\mathrm{MJ} / \mathrm{kg} \mathrm{DM}$, respectively. In conclusion, it was found that soaked treatment applied to common vetch seed was preferable rather than other physically treated seeds.

Keywords:

Vica sativa

Physical treatment

Chemical composition

In vitro gas production Feed value

\section{Introduction}

It is reported that vetch, which has an important place in legume species, can be used as both roughage and concentrate for ruminant (Yolcu and Tan, 2008). Almost all of the vetch species cultivated from Asia-Europe and especially Mediterranean countries origin of our country is reported to be very rich in terms of vetch species of natural vegetation (Turgut et al., 2006). In Turkey, even the most widely grown and known species of vetch species in the world, it is common vetch (Vicia sativa L.). Both the vegetative parts and grains of the legume family vetch are used in various forms for animal feeding. Common vetch used in animal feeding is used as dry grass, green grass, alternation plant, seed production, pasture plant and silo feed as well as grain (Kaya and Turgut, 2008). It contains antibacterial factors such as cyano glycoside, tannin, lectin, anti-vitamin factors, hydrocyanic acid, neurotoxic amino acids that give the seed a bitter taste to the seed called vicin and convicin (Farran et al., 2001; Budağ and Bolat, 2003). Therefore, the use of legume seeds in ruminant nutrition, particularly in high-producing, is limited and the utilization is inefficient under certain conditions. In addition, legume seeds contain antinutritional compounds that depending upon seed and phonological conditions have different effects on livestock body ( $\mathrm{Yu}$ et al., 2002). Different processing techniques are used to eliminate these antibacterial factors or to increase the nutritional value of legume grains. These; grain integrity degradation (grinding and crushing), grain shell removal, heat treatment (dry heat roasting, cooking in water, steam treatment and various chemical substances), can be listed in the form of fermentation (Yalçın and Onbaşılar, 2001).

It is reported that the effects of the feeds to be used in animal nutrition will be determined in animals and an assessment should be made accordingly and that animals will be fed sufficiently and economically only with such an assessment (Gürsoy 2013). Gas production technique is a direct method based on the measurement of $\mathrm{CO}_{2}$ gas produced by fermentation after incubation of feeds with rumen liquid and allows calculation of many parameters using $\mathrm{CO}_{2}$ gas. A significant and high correlation was reported between the parameters, determined in gas production technique, and the performance of the animals 
(Qrskov 1982), feed consumption (Blummel and Qrskov, 1993), microbial protein digestion (Krishnamoorthy et al., 1991), the degree of in vivo digestion of feeds (Khazaal et al., 1993).

The aim of present study was to determine the organic matter digestibilities (OMD), metabolizable energy (ME), net energy lactation (NEL) contents, chemical compositions and nutritive values of different physical treated (raw, soaked, boiled and roasted) common vetch seeds (Vicia sativa) by in vitro gas production technique.

\section{Material and Method}

This experiment was conducted by the researchers based on protocols by Atatürk University Ethical Commission Report (No: 24.02.2014/1/19).

Ruminal fluid was obtained from a cannulated Holstein Friesain cow before the morning feeding. Holstein Friesain bull of $650 \mathrm{~kg}$ and 7 years of age was housed individually on concrete floor and fed according to $1.25 \mathrm{x}$ maintenance ration containing $55 \%$ concentrate, $20.5 \%$ dried grass, $20.5 \%$ alfalfa hay and $4 \%$ wheat straw. Animal was offered ad libitum water throughout the experiment. Ruminal fluid was immediately filtered trough 4 layers of cheesecloth and was transported to the laboratory in sealed thermos. The resulting ruminal fluid was purged with deoxygenated $\mathrm{CO}_{2}$ before use as the inoculum. Locally produced common vetch seeds (C) (Vicia sativa L.) were soaked (SC) in water at room temperature in the ratio of 1:5 (w/v) for six days with a water change every 72 hours then dried at room temperature, boiled (BC) at $100^{\circ} \mathrm{C}$ for 30 minutes and then dried at $60^{\circ} \mathrm{C}$ for 24 hours and roasted (RC) at $130^{\circ} \mathrm{C}$ for 30 minutes in drying oven (Kaya et al., 2011).

\section{Chemical Analyses}

Vetch seeds grinded using a $1 \mathrm{~mm}$ screen diameter mill and dry matter (DM), crude protein $(\mathrm{CP})$, ether extract (EE), crude ash (CA) of treatment groups were analyzed according to AOAC (2000). Fiber analysis (ADF, NDF and ADL) was done using Ankom Fiber Analyser 2000 (ANKOM Technology, Macedon, NY) (Van Soest et al 1991).

\section{In Vitro Gas Production}

Modified in vitro gas production technique was applied to measure the total gas production of the feed samples in this study (Menke et al., 1979; Menke and Steingass 1988; Blummel and Ørskov, 1993). Approximately $200 \mathrm{mg}$ common vetch samples (on a dry matter basis) milled through a $1 \mathrm{~mm}$ sieve were incubated as in vitro in rumen fluid in $100 \mathrm{ml}$ glass vials with six replicates following the procedures of Menke and Steingass (1988). The glass vials were prewarmed at $39^{\circ} \mathrm{C}$ and $30 \mathrm{ml}$ of rumen fluid buffer mixture including $10 \mathrm{ml}$ rumen fluid and $20 \mathrm{ml}$ buffer solution was transferred into each vial and then they were incubated at $39^{\circ} \mathrm{C}$ in a water bath to determine the amount of gas produced in tubes at the 2, 4, 6, 8, 16, 24, 36, 72 and 96th of incubation times (Blummel and Ørskov, 1993). To imitate the peristaltic movements of the rumen, water engines providing movement in the water bath were used during the incubation times. Cumulative gas production data were fitted to the model Ørskov and McDonald (1979) by NEWAY computer package programme.

$$
\mathrm{Y}=\mathrm{a}+\mathrm{b}\left(1-\mathrm{e}^{-\mathrm{ct}}\right)
$$

Where, $\mathrm{a}$ is the gas production from the immediately soluble fraction $(\mathrm{mL}), \mathrm{b}$ is the gas production from the insoluble fraction $(\mathrm{mL}), \mathrm{c}$ is the gas production rate constant for insoluble fraction $\left(\mathrm{mL} \mathrm{h}^{-1}\right), \mathrm{a}+\mathrm{b}$ is the potential gas production $(\mathrm{mL}), \mathrm{t}$ is incubation time $(\mathrm{h}), \mathrm{y}$ is gas produced at time $t$.

Organic matter digestibility (OMD,\%), metabolic energy (ME, MJ/kgKM; Menke et al., 1979) and net energy lactation $\left(\mathrm{NE}_{\mathrm{L}}, \mathrm{MJ} / \mathrm{kg} \mathrm{KM}\right)$ values (Menke and Steingass, 1988) of common vetch samples were calculated according to the given below formulas:

$$
\begin{aligned}
& \text { OMD } \%=14.88+0.8893 \mathrm{GP}+0.448 \mathrm{CP}+0.0651 \mathrm{CA} \\
& \mathrm{ME}=2.20+0.136 \mathrm{GP}+0.0574 \mathrm{CP}+0.00286 \mathrm{CF} 2 \\
& \mathrm{NE}_{\mathrm{L}}=0.101 \mathrm{GP}+0.051 \mathrm{CP}+0.112 \mathrm{EE} \\
& \text { Where: } \\
& \mathrm{GP}: 24 \text { h net gas production }(\mathrm{mL} / 200 \mathrm{mg} \mathrm{DM}) \\
& \mathrm{CP}: \text { Crude protein }(\%) \\
& \mathrm{EE}: \text { Ether extract }(\%) \\
& \mathrm{CA}: \text { Crude ash content }(\%)
\end{aligned}
$$

\section{Statistical Analysis}

The data were analysed in SPSS 17.0 (2004) package program and the differences among the group averages were determined by Duncan Multiple Comparison Test (Snedecor and Cochran, 1976).

\section{Results and Discussion}

The difference between vetch groups was found significant in terms of all parameters examined regarding chemical compositions $(\mathrm{P}<0.01)$. Dry matter content of vetch seeds may vary depending on factors such as harvest time, apart from feed source, vegetation period, climate, soil etc. (Kılıç and Sarıçiçek, 2006). The moisture content is very important for the preservation and storage of feeds. If the feed dry matter content is required less than $85 \%$, distortion begins and loses nutritive effect of feed (Alçiçek et al., 1997). It can be said that the high content DM of soaked and boiled vetch groups is caused by the increase of the surface areas of the water treated grains volumetric in this study. The increase in the amount of crude ash means the decrease in the amount of organic matter. Therefore, the vetch groups organic matter content, calculated based on the crude ash content of samples, was determined with the highest soaked vetch and the lowest with raw vetch. It is not correct to express the whole of crude ash as inorganic nutrients. Because besides inorganic nutrients, if there are elements such as dust, soil, sand in the feed, these are also defined as crude ash fraction (Akylldiz, 1986). Therefore, the reason for the low proportion of CA in boiled vetch and the high content of OM may be due to the fact that the boiling process purifies foreign materials (sand, soil, grass, etc.) in the feed sample. The EE and CP contents of the vetch groups were determined between $2.28 \%-3.29 \%$ and $25.41 \%-32.83 \%$ respectively. 
Table 1. Chemical composition of common vetch seed groups (\%)

\begin{tabular}{l|ccccccc}
\hline Groups & DM & CA & EE & CP & NDF & ADF & ADL \\
\hline C & $89.50^{\mathrm{b}}$ & $2.69^{\mathrm{a}}$ & $3.29^{\mathrm{a}}$ & $25.41^{\mathrm{d}}$ & $19.74^{\mathrm{b}}$ & $9.94^{\mathrm{c}}$ & $1.56^{\mathrm{b}}$ \\
SC & $94.50^{\mathrm{a}}$ & $2.11^{\mathrm{b}}$ & $2.28^{\mathrm{b}}$ & $32.83^{\mathrm{a}}$ & $20.42^{\mathrm{b}}$ & $5.59^{\mathrm{d}}$ & $0.57^{\mathrm{c}}$ \\
RC & $92.66^{\mathrm{a}}$ & $2.43^{\mathrm{ab}}$ & $2.77^{\mathrm{ab}}$ & $29.01^{\mathrm{c}}$ & $34.19^{\mathrm{a}}$ & $16.68^{\mathrm{a}}$ & $2.62^{\mathrm{a}}$ \\
BC & $93.58^{\mathrm{a}}$ & $1.43^{\mathrm{c}}$ & $2.62^{\mathrm{b}}$ & $30.74^{\mathrm{b}}$ & $34.64^{\mathrm{a}}$ & $11.10^{\mathrm{b}}$ & $1.69^{\mathrm{b}}$ \\
SEM & 0.62 & 0.13 & 0.16 & 0.31 & 1.22 & 0.34 & 0.15 \\
P & 0.002 & 0.001 & 0.015 & 0.000 & 0.000 & 0.000 & 0.000 \\
\hline
\end{tabular}

a,b,c,d: Means within columns with different superscripts differ at P<0.05. SEM: Standart Error Mean; C: Untreated common vetch seed, SC: Soaked common vetch seed, RC: Roasted common vetch seed, BC: Boiled common vetch seed.

Table 2. In vitro gas production values ( $\mathrm{ml} / 200 \mathrm{mg} \mathrm{DM})$ and parameters

\begin{tabular}{l|cccccc}
\hline \multicolumn{1}{c}{ Hours } & $\mathrm{C}$ & $\mathrm{SC}$ & $\mathrm{RC}$ & $\mathrm{BC}$ & SEM & $\mathrm{P}$ \\
\hline 2 & $7.50^{\mathrm{a}}$ & $4.57^{\mathrm{b}}$ & $3.17^{\mathrm{bc}}$ & $1.67^{\mathrm{c}}$ & 0.544 & 0.000 \\
4 & $12.87^{\mathrm{a}}$ & $8.87^{\mathrm{b}}$ & $6.46^{\mathrm{c}}$ & $1.77^{\mathrm{d}}$ & 0.304 & 0.000 \\
6 & $17.96^{\mathrm{a}}$ & $13.50^{\mathrm{a}}$ & $6.47^{\mathrm{b}}$ & $6.60^{\mathrm{b}}$ & 1.503 & 0.002 \\
8 & $26.77^{\mathrm{a}}$ & $23.23^{\mathrm{a}}$ & $14.63^{\mathrm{b}}$ & $15.17^{\mathrm{b}}$ & 1.094 & 0.000 \\
12 & $36.23^{\mathrm{a}}$ & $37.27^{\mathrm{a}}$ & $27.06^{\mathrm{b}}$ & $30.00^{\mathrm{b}}$ & 2.319 & 0.040 \\
16 & $44.17^{\mathrm{ab}}$ & $48.90^{\mathrm{a}}$ & $34.60^{\mathrm{c}}$ & $36.07^{\mathrm{bc}}$ & 2.765 & 0.019 \\
24 & $53.03^{\mathrm{ab}}$ & $59.97^{\mathrm{a}}$ & $39.83^{\mathrm{c}}$ & $46.30^{\mathrm{bc}}$ & 3.850 & 0.030 \\
36 & $58.93^{\mathrm{ab}}$ & $66.67^{\mathrm{a}}$ & $49.27^{\mathrm{c}}$ & $53.93^{\mathrm{c}}$ & 3.497 & 0.039 \\
48 & 63.80 & 70.93 & 55.80 & 59.47 & 3.615 & 0.082 \\
72 & 66.80 & 74.03 & 61.57 & 64.20 & 3.439 & 0.140 \\
96 & 70.13 & 76.83 & 67.07 & 68.27 & 3.287 & 0.233 \\
$\mathrm{pH}$ & 6.65 & 6.70 & 6.64 & 6.65 & 0.073 & 0.924 \\
$\mathrm{~B}$ & 66.92 & 85.64 & 70.68 & 77.58 & 5.51 & 0.162 \\
$\mathrm{~A}+\mathrm{B}$ & 63.09 & 75.81 & 66.11 & 66.71 & 4.61 & 0.308 \\
$\mathrm{C}$ & 0.070 & 0.023 & 0.014 & 0.037 & 0.025 & 0.454 \\
\hline
\end{tabular}

a,b,c,d: Means within row with different superscripts differ at P<0.05. SEM: Standart Error Mean; C: Untreated common vetch seed, SC: Soaked common vetch seed, RC: Roasted common vetch seed, BC: Boiled common vetch seed. A+B potential gas production (ml); C: fractional rate of gas production during incubation $(\mathrm{ml} / \mathrm{h})$

When the results obtained from the current study are compared with other studies related to common vetch, It was observed that was similar to the findings of the study conducted to calculate the nutritional values of broken vetch (Round 1989), was lower than the data obtained by Fernandes Abreu and Bruno-Soares (1998) their study to determine the chemical composition and OM digestibility of the nine legume varieties, and from the data obtained by Gonzalez and Andres (2003) from their study to determine the effective KM and HP values of some legume seed and was higher than the data obtained by Küçükersan (1993) his in vitro study with common vetch. This may be due to the differences in laboratory conditions, cultural (harvest time, fertilization, irrigation, etc.) and physical (soaking, boiling, autoclaving, roasting, etc.) treatments.

In this study, the NDF, ADF and ADL contents of vetch groups were determined between 19.74-34.64\%, 5.59$16.68 \%$ and $0.57-2.62 \%$ respectively. The difference between the groups in terms of ADF, NDF and ADL values were to be significant $(\mathrm{P}<0.05)$. It is thought that especially temperature treatments such as boiling and roasting applied to the vetch can increase the ADF and NDF fractions, some insoluble carbohydrates such as cellulose and hemicellulose in neutral and acid detergents by converting it into soluble form. Another theory is that some temperature-damaged proteins are also found in the NDF fraction (Kutlu, 2008). This strengthens the hypothesis that temperature treatment may have increased the NDF value in feed.

\section{In Vitro Gas Production Values of Treatment Groups}

Cumulative gas volumes at 2, 4, 6, 8, 12, 16, 24, 36, 48, 72 and $96 \mathrm{~h}$ after incubation are shown in Table 2. The result showed that cumulative gas production at $2,4,6,8$, $12,16,24$ and $36 \mathrm{~h}$ after incubation differed significantly $(\mathrm{P}<0.05)$. At $24 \mathrm{~h}$ after incubation time, the highest gas production, which were taken into account in calculation of ME, NEL and OMS values, were obtained from SC group (59.97 ml / $200 \mathrm{mg} \mathrm{DM})$. There was no significant difference between the groups in terms of $\mathrm{A}+\mathrm{B}$ value indicating the potential gas production value $(\mathrm{P}>0.05)$.

It was determined that there was no significant difference $(\mathrm{P}>0.05)$ in terms of vetch groups $\mathrm{pH}$ values, measured at $96 \mathrm{~h}$ after incubation time, and $\mathrm{pH}$ values were between $6.64-6.70$. It can be said that the roasting and boiling treatment applied to the vetch seeds examined produced less gas than other vetch groups due to the cellulose and ADL contents increased in the study.

Cone and Gelder (1999) reported that gas production was positively affected by decreased NDF, ADF and ADL content of feed, due to increased energy content and protein content. It was determined that the results of in vitro gas production values in this study are similar to the some study (Raund 1989; Küçükersan 1993; Makkar at al. 1997) results related to vetch seeds. It was determined that there were differences in terms of vetch groups in vitro gas production parameters $(\mathrm{P}<0.01)$. The difference between the groups in terms of "B" value, which is an expression of the amount of gas formed in time, and $\mathrm{A}+\mathrm{B}$ values, the indicators of potential gas production, and " $C$ " value, 
indicates the gas production rate of the feed, were insignificant $(\mathrm{P}>0.05)$.

When the results obtained in terms of vetch feed samples gas production parameters compared with other studies related to the subject, in terms of "B, $C$ " values and "A + B" values similar to the findings of Aguilera et al. (1992), Hadjipanayiotou and Economides (2001), Küçükersan (1993), but it was determined for vetch were higher than the values reported by Sui (2018); Boga et al., (2014) and lower than results of Gonzalez and Andres (2003), Canbolat and Karaman (2009). These differences may have resulted from the different physical treatments, the applied methods and the used feed material.

\section{Organic Matter Digestibility, Metabolizable Energy and Net Energy Lactation}

$\mathrm{ME}, \mathrm{NE}_{\mathrm{L}}$ and DOM of the feedstuffs are shown in Table 3. The values for the $\mathrm{ME}, \mathrm{NE}_{\mathrm{L}}$ and $\mathrm{DOM}$ ranged from in 11.23 RC to 14.55 in SC, 5.81 in RC to 7.99 in SC and 63.50 in $\mathrm{RC}$ to 83.10 in $\mathrm{SC}$, respectively.

Table 3. Gas production estimated parameters of vetch seeds

\begin{tabular}{l|ccc}
\hline Groups & $\begin{array}{c}\mathrm{ME} \\
(\mathrm{MJ} / \mathrm{kg} \mathrm{DM})\end{array}$ & $\begin{array}{c}\mathrm{NE}_{\mathrm{L}} \\
(\mathrm{MJ} / \mathrm{kg} \mathrm{DM})\end{array}$ & $\begin{array}{c}\text { OMD } \\
(\%)\end{array}$ \\
\hline $\mathrm{C}$ & $12.27^{\mathrm{b}}$ & $7.02^{\mathrm{ab}}$ & $73.64^{\mathrm{ab}}$ \\
$\mathrm{SC}$ & $14.55^{\mathrm{a}}$ & $7.99^{\mathrm{a}}$ & $83.10^{\mathrm{a}}$ \\
$\mathrm{RC}$ & $11.23^{\mathrm{b}}$ & $5.81^{\mathrm{b}}$ & $63.50^{\mathrm{b}}$ \\
$\mathrm{BC}$ & $11.85^{\mathrm{b}}$ & $6.54^{\mathrm{b}}$ & $69.97^{\mathrm{b}}$ \\
SEM & 0.63 & 0.39 & 3.44 \\
$\mathrm{P}$ & 0.026 & 0.025 & 0.022 \\
\hline
\end{tabular}

a,b: Means within columns with different superscripts differ at $\mathrm{P}<0.05$ SEM: Standart Error Mean, C: Untreated common vetch seed, SC: Soaked common vetch seed, RC: Roasted common vetch seed, BC: Boiled common vetch seed $\mathrm{OMD}=$ Digestible organic matter, $\mathrm{ME}=$ metabolizable energy, $\mathrm{NE}_{\mathrm{L}}=$ Net energy lactation

Low determination of RC metabolizable energy can be resulted from its low rate of gas production and extent of gas production at $24 \mathrm{~h}$. For gas volume and in vitro gas production characteristics, (Menke and Steingass, 1988) suggested that gas volume at $24 \mathrm{~h}$ after incubation is an indirect relationship with ME in feedstuffs. Gas production can be regarded as an indicator of carbohydrates degradation; (Steingass and Menke, 1986) suggested that gas volume is a good parameter from which to predict digestibility, fermentation end product and microbial protein synthesis of the substrate by rumen microbes in the in vitro system. Gas production is basically the result of fermentation of carbohydrates to acetate, propionate and butyrate (Steingass and Menke, 1986) and substantial changes in carbohydrates fractions were reflected by total gas produced. It was determined that the highest OMD value was in soaked vetch $(83.10 \%)$ and the lowest OMD value was roasted vetch $(63.50 \%)$. The increase in $\mathrm{CP}$ content and the amount of gas produced at $24 \mathrm{~h}$ after incubation time ours in the soaked vetch seeds increased the level of OMD. It is reported by Round (1989) that feeds rich in nutrients that are difficult to dissolve in the rumen such as NDF, ADF and ADL reduce the amount of OMD by limiting microbial fermentation.

In present study, ME, NEL and OMD values determined in this study were higher than those reported by
Uslu et al. (2018), Küçükersan (1993), Kaya and Yalçın (2000) and lower than stated by Goelama et al. (1998), Yu et al. (2002) and similar to the findings of Ressler et al. (1997). Because the factors such as the soil structure where the feedstuffs are grown, the variation of the feed, the harvest period are effective on the digestibility of the feedstuffs and thus the ME content, it is observed that similar results can be obtained in the same type of feed samples, as well as different results.

There were significant differences among the vetch seeds in terms of chemical composition. The differences in chemical composition of vetch groups resulted in the differences in the in vitro gas production and the estimated parameters such as ME, NE and OMD. As a result, considering the findings obtained from the research, while physical treatments such as roasting and boiling to vetch seeds have negative effects on the $\mathrm{OMD}, \mathrm{ME}$ and $\mathrm{NE}_{\mathrm{L}}$ values, soaking treatment significantly improved these parameters compared to vetch seeds in both raw vetch and other treatment groups. Considering the chemical composition and in vitro parameters of the feedstuffs, it can be said that the soaking treatment is more suitable for vetch seed.

\section{Acknowledgements}

This work was supported by the Scientific Research Projects Fund of Ataturk University under Grant number PRJ2012/407.

The article was extracted from the master thesis prepared by Yasemin Işık under the guidance of Assoc. Prof. Dr. Adem Kaya

\section{References}

Aguilera JF, Bustos M, Molina E. 1992. The degradability of legume seed meals in the Rumen: Effect of heat treatment. Animal Feed Science and Technology, 36:101-112.

Aky1ldız AR. 1986. Yemler bilgisi ve teknolojisi. Ankara Üniv. Ziraat Fak. Yay. No: 974, Ders Kitabı No:286, 411, Ankara.

Alçiçek A, Akdemir H, Erkek R. 1997. Farklı mısır varyetelerinin agronomik özellikleri, silolanma kabiliyeti ve yem değeri üzerine araştırmalar: 2. Silolanma Kabiliyeti ve Yem Değeri. Türkiye I. Silaj Kongresi, Bursa. Turkey, pp: 235-240,

AOAC. 2000. Official Methods of Analysis. (17th Ed.). Maryland, USA: Association of Official Analytical Chemists.

Blummel M, Ørskov ER. 1993. Comparison of in vitro gas production and nylon bag degradability of roughages in predicting feed intake in cattle. Animal Feed Science and Technology, 40(2-3): 109-119.

Boga M, Yurtseven S, Kilic U, Aydemir S, Polat T. 2014. Determination of nutrient contents and in vitro gas production values of some legume forages grown in the Harran plain saline soils. Asian-Australasian Journal of Animal Science 27(6): 825-831.

Budağ C, Bolat D. 2003. Koyunlarda farklı protein kaynaklarının mikrobiyal protein sentezi üzerine etkisi. II. Ulusal Hayvan Besleme Kongresi, Konya, Turkey.18-20 Eylül 2003. pp: 113-116.

Canbolat Ö, Karaman Ş. 2009. In vitro gas production, organic matter digestion, relative feed value and metabolic energy contents of some legume roughages. Journal of Agriculturel Science, 15 (2): 188-195.

Cone JW, Van Gelder AH. 1999. Influence of protein fermentation on gas production profiles. Animal Feed Science and Technology, 76:251-256. 
Farran MT, Dakessian PB, Darwish AH, Uwayjan MG, Dbouk HK, Sleiman FT, Ashkarian VM. 2001. Performance of broilers and production and egg quality parameters of laying hens fed $60 \%$ raw or treated common vetch seeds. Poultry Science, 80: 203-208.

Fernandes Abreu JM, Bruno-Soares AM. 1998. Chemical composition, organic matter digestibility and gas production of nine legume grains. Animal Feed Science and Technology, 70: 49-57.

Goelema JO, Spreeuwenberg MAM, Hof G, van der Poel AFB, Tamminga S. 1998. Effect of pressure toasting on the rumen degradability and intestinal digestibility of whole and broken peas, lupins and faba beans and a mixture of these feedstuffs. Animal Feed Science and Technology, 76: 35-50

Gonzalez J, Andres S. 2003. Rumen degradability of some feed legume seeds. Animal Research 52:17-25.

Gürsoy E. 2013 Erzurum ili meralarında doğal olarak yetişen bazı baklagil ve buğdaygil kaba yem bitkilerinin kimyasal bileşimleri, nispi yem değerleri ve in vitro gaz üretim değerlerinin belirlenmesi. Alınteri Journal of Agricultural Sciences. 32(1):1-9.

Hadjipanayiotou M, Economides S. 2001. Chemical composition, in situ degradability and amino acid composition of protein supplements fed to livestock and poultry in Cyprus. Agricultural Resarch Institue, 1516 nicosia, P.O. Box 22016, 6, Cyprus.

Karabulut A, Canpolat Ö, Kalkan H, Gürbüzol F. Sucu E, Filya İ. 2007. Comparison of in vitro Gas Production, Metabolizable Energy, Organic Matter Digestibility and Microbial Protein Production of Some Legume Hays. Asian-Agustralasian Journal of Animal Science, 20:4, 517-522.

Kaya H, Çelebi Ş, Macit M, Geyikoğlu F. 2011. The Effects of raw and physical processed common vetch seed (Vicia sativa) on laying performance, egg quality, metabolic parameters and liver histopatology of laying hens. Asian-Agustralasian Journal of Animal Science, 24: 1425-1434.

Kaya A, Turgut L. 2008. Değişik fiziksel muamelelere tabi tutulan sorgum (sorgum vulgare) naylon torba tekniği ile rumende parçalanabilirlik paramentlerinin belirlenmesi. Hayvansal Üretim, 49 (2): 23-28.

Kaya İ, Yalçın S. 2000. Kuzu konsantre yemlerine farklı oranlarda katılan adi fiğin besi performansı, sindirilme derecesi ile bazı kan ve rumen sıvısı metabolitleri üzerine etkisi. Turkish Journal of Veterinary and Animal Science, 24: 307-315.

Khazaal K, Dentinho MT, Ribeiro JM, Ørskov ER. 1993. A comparison of gas production during incubation with rumen contents in vitro and nylon bag degradability as predictors of the apparent digestibility in vivo and the voluntary intake of hays. Animal Production, 57 (1): 105-112.

Kılıç Ü, Sarıçiçek BZ. 2006. In vitro gaz üretim tekniğinde sonuçları etkileyen faktörler. Hayvansal Üretim, 47(2): 54 61.

Krishnamoorty U, Soller H, Steingass H, Menke KH. 1991. A comparative study on rumen fermentation of energy supplements in vitro. Journal of Animal Physiology and Nutrition, 65: 28-35.

Kutlu HR. 2008. Yem değerlendirme ve analiz yöntemleri. Çukurova Üniversitesi Ziraat Fakültesi Zootekni Bölümü. Ders notu. Z.M. 208. Adana.

Küçükersan S. 1993. Bazı protein saplementleri ve kaba yemlerin naylon kese tekniği ile yıkılabilirlik derecelerinin incelenmesi. (Doktora Tezi). Ankara Üniversitesi Sağl1k Bilimleri Enstitüsü Hayvan Besleme ve Besleme Hastalıkları Anabilim Dalı, 140, Ankara.
Makkar Harinder PS, Becker K, Abel HJ, Pawelzik E. 1997. Nutrient contents, rumen protein degradability and antinutritional factors in some colour-and White flowering cultivars of vicia faba beans. Journal of the Science of Food and Agriculture, 75: 511-520.

Menke KH, Raab LL, Salewski A, Steingass H, Fritz Schneider W. 1979. The estimation of digestibility and metabolizable energy content of ruminant feeding stuffs from the gas production when they are incubated with rumen liqueur in vitro. Journal of Agricultural Science, 93: 217-222.

Menke K, Steinggass H. 1988. Estimation of the energetic feed value from chemical analyses and in vitro gas production using rumen fluid. Animal Research and Development, 28: 47-55.

Ørskov ER, McDonald I. 1979. The estimation of protein degradability in the rumen from incubation measurements weighted according to rate of passage. The Journal of Agricultural Science, 92(02): 499-503.

Ressler C, Tatake JG, Kaizer E, Putnam DH. 1997. Neurotoxins in a vetch food: Stability to cooking and removal of $\gamma$ glutamyl- $\beta$-cyanoalanine and acute toxicity from common vetch (Vicia sativa L.) legumes. Journal of Agricultural and Food Chemistry, 45: 189-194.

Round MH. 1989. Vetch seed as a feed for sheep. Nutr. Abstr. Rev. B., 11: 642. SPSS, 1999. SPSS for Windows Release 10.0, SPSS Inc. Chicago.

SPSS. 2004. Windows User's Guide. Version 13.0, SPSS Inc., Michigan Ave., Illinois, USA., Chicago.

Steingass H, Menke KH. 1986. Schatzung des energetischen Futterwertes aus der in vitro pansensaft bestimmten Gasbildung und der chemischen analysis. Tirerenahrung. 14:251.

Sui MX. 2018. Correlation research between gas production characteristics and CNCPS components for roughages. 4th International Conference on Agricultural and Biological Sciences. Earth and Environmental Sciences, 185: doi:10.1088/1755-1315/185/1/012015.

Turgut L, Yanar M, Kaya A, Tan M. 2006. Farklı olgunluk dönemlerinde hasat edilen bazı fiğ türlerinin ham besin maddeleri içeriği ve bunların in situ rumen parçalanabilirlikleri. Atatürk Ünivversitesi Ziraat Fakültesi Dergisi, 37 (2): 181-186.

Van Soest PJ, Robertson JD, Lewis BA. 1991. Methods for dietary fibre, neutral detergent fibre and non-starch polysaccharides in relation to animal nutrition. Journal of Dairy Science, 74: 3583-3597.

Qrskov ER. 1982. Protein nutrition in ruminants. Academic press (2nd ed.), 175, London.

Uslu OS, Kurt O, Kaya E, Kamalak A. 2018. Effect of species on chemical composition, metabolizable energy, organic matter digestibility and methane production of some legume plants grown in Turkey. Journal of Applied and Animal Research, 46(1):1158-1161.

Yu P, Egan AR, Boon-ek L, Leury BJ. 2002. Purine derivative excretion and ruminal microbial yield in growing lambs fed raw and dry roasted legume seeds as protein supplements. Animal Feed Science and Technology, 95: 33-48.

Yalçın S, Onbaşılar İ. 2001. Dane yem olarak adi fiğin kanatlı ve ruminant rasyonlarında kullanımı. Yem Magazin Dergisi, 27: 37-43.

Yolcu H, Tan M. 2008. Ülkemiz yem bitkileri tarımına genel bir bakış. Tarım Bilimleri Dergisi, 14 (3): 303-312. 